\title{
SOSIALISASI KREASI PENGOLAHAN SAMPAH MELALUI PROGRAM “DECOU-SANTAI” DALAM MENINGKATKAN PENGHASILAN MASYARAKAT SERTA KEPEDULIAN TERHADAP LINGKUNGAN PESISIR PANTAI CIPATUJAH
}

\author{
(Program Pengabdian Pada Masyarakat Di Desa Cipatujah Kec.Cipatujah \\ Kabupaten Tasikmalaya)
}

\author{
Novi Widiastuti 1 \\ Prita Kartika ${ }^{2}$ \\ 1, 2 .IKIP SILIWANGI BANDUNG \\ 1noviw9@gmail.com
}

\begin{abstract}
ABSTRAK
Kabupaten Tasikmalaya Jawa Barat terkenal sebagai daerah dengan destinasi wisata pantai yang sangat indah. Salah satu pantai selain pantai pangandaran yang juga memiliki keindahan pantainya yaitu pantai cipatujah yang terletak di Desa Sindangkerta. Pantai Cipatujah memiliki luas hingga 115 hektar yang kaya akan terumbu karang untuk ikan-ikan bertelur dan berkembangbiak. Pantai Cipatujah kini dilengkapi dengan berbagai fasilitas seperti hotel, restoran, warung-warung, dan tempat parker yang luas. Sebagai pantai yang menjadi destinasi wisata, pantai cipatujah kini mengalami beberapa dampak positif dan negatif yang dirasakan oleh masyarakat secara langsung maupun tidak langsung. Dampak positif yang dirasakan adalah terbukanya lapangan pekerjaan baru maupun lahan usaha baru yang tentunya menjadi peluang yang menjanjikan bagi masyarakat. Banyaknya pembangunan seperti hotel, restoran, dan tempat umum lainnya menyerap banyak tenaga kerja. Namun disamping dampak positif, terdapat juga dampak negatif yang dirasakan oleh masyarakat secara tidak langsung yaitu kerusakan lingkungan akibat rendahnya kepedulian masyarakat sebagai pengunjung dalam menjaga lingkungan sekitar.

Sampah di pesisir pantai menjadi masalah baru yang dihadapi oleh masyarakat setempat. Oleh karena itu, pengolahan sampah menjadi solusi yang tepat untuk mengembalikan kelestarian lingkungan dan juga dapat menambah daya tarik para wisatawan domestic maupun mancanegara. Sampah yang sering ditemukan adalah sampah plastic seperti botolbotol platik bekas minuman, botol kaleng, dan dan botol kaca. Melalui program "DecouSantai" yang merupakan akronim dari Decoupage Sampah Pantai ini diharapkan masyarakat memiliki keterampilan dalam mengolah sampah pantai menjadi barang yang dapat dimanfaatkan kembali. Selain itu sampah yag diolah kembali bisa menjadi barang yang memiliki nilai jual yang tinggi sebagai cendramata khas pantai cipatujah. Program ini juga memberikan kesempatan bagi ibu-ibu rumah tangga untuk menambah penghasilan dalam memenuhi kebutuhan hidup masyarakat.
\end{abstract}

Kata Kunci : Melestarikan Lingkungan Pantai, Peningkatan Ekonomi, Program Pengolahan Sampah, Sampah Pantai

\begin{abstract}
Tasikmalaya regency of West Java is famous as an area with a very beautiful beach destination. One of the beaches in addition to Pangandaran beach which also has the beauty of the beach is Cipatujah beach located in the Village Sindangkerta. Cipatujah Beach has an area of up to 115 hectares rich in coral reefs for laying and breeding fish. Cipatujah Beach is now equipped with various facilities such as hotels, restaurants, stalls, and a large parking area. The beach is a tourist destination, beach cipatujah now experience some positive andnegative impacts felt by the community directly or indirectly. Positive impacts are perceived to be divided into new jobs or new business land which is certainly a promising opportunity for the community. The number of developments such as hotels, restaurants, and other public places a lot of manpower. Both in addition to the positive impact, there are
\end{abstract}


also negative impacts felt by the community directly there is no environmental damage due to low public awareness as a visitor in the surrounding environment. Coastal trash is a new problem that is being developed by local people. Therefore, waste processing to be the right solution to help environmental sustainability and also can increase the attractiveness of the domestic and foreign tourists. Rubbish that is often found is plastic waste such as beverage used plastic bottles, bottles cans, and and glass bottles. Through the program "Decou-Relax" which is an acronym of Decoupage Coast Trash is expected people have skills in processing waste beach into goods that can be reused. In addition, the waste is re-processed yag can be goods that have high selling value as a typical cendramata beach cipatujah. This program also provides an opportunity for housewives to increase income to meet the needs of community life.

Keywords: Preserve Coastal Environment, Economic Improvement, Waste Processing Program, Coastal Waste

\section{A. PENDAHULUAN}

Desa Sindangkerta, kecamatan cipatujah tasikmalaya ini kini menjadi destinasi wisata yang memberikan warna tersendiri bagi dunia pariwisata Jawa Barat. Pantai dengan luas 115 Hektar ini memiliki keindahan yang tidak kalah indah dengan pantai lainnya yang sudah lebih dulu dikenal di masyarakat. Berdasarkan penelitian yang dilakukan oleh Agustine (2012:1) menyebutkan bahwa

Pesisir Cipatujah memiliki banyak potensi wisata yang cukup menarik seperti alunan ombak yang besar, pantai, sunset, panorama laut lepas, wisata bahari, pantai pasir putih, dan berjenis pasir besi sehingga sangat baik untuk berjemur dan melakukan aktivitas rekreasi pantai lainnya, serta adat istiadat dan kebudayaan yang mengundang daya tarik tersendiri bagi pengunjungnya.

Hal ini terlihat dari peningkatan jumlah wisatawan dari tahun 2011-2013 menurut data dinas pariwisata dan kebudayan tasikmalaya tahun 2014 (Mulyadin, 2014) yaitu 11.927 pada tahun 2013 dan menjadi 18.447 pada tahun 2013. Namun hal ini masih belum mencapai target master plan Cipatujah, sehingga pemerintah setempat perlu meningkatkan daya tarik lain sebagai destinasi wisata.

Oleh karena itu pada tahun 2014 mulai dikembangkan beberapa kegiatan sebagai penarik wisatawan yaitu (Mulyadin, 2014) "Hajatan lembur, balapan kerbau, pesta kembang api (tahun baruan), dan festival laying-layang". Namun kegiatan yang paling diminati pengunjung yakni kegiatan "kumpul kebo" yaitu berkumpul bersama kerbau. Kumpul kebo disini adalah kegiatan balap kerbau yang diadakan di pantai Cipatujah menarik wisatawan untuk berkunjung.

Kini semakin banyak wisatawan yang berkunjung maka semakin banyak memberikan dampak pada kehidupan masyarakat cipatujah. Dampak positif maupun negatif timbul akibat ramainya pantai cipatujah. Adapun dampak positif diantaranya adalah menyerap 
tenaga kerja baru di lingkungan pesisir pantai karena banyaknya dibangun hotel, restoran, serta warung-warung kecil. Banyak sekali jasa yang bias ditawarkan pada wisatawan yang berkunjung seperti jasa mentato, jasa pijat, sampai jasa penyewaan tikar untuk sekedar makan bersama di pinggir pantai.

Hal ini memberikan efek positif pada penghasilan warga sekitar. Namun bukan hanya dampak positif yang ditimbulkan, ramainya pantai menjadi lingkungan kotor, dan banyak sampah yang menumpuk di pinggri pantai akibat wisatawan yang kurang bertanggung jawab. Menurut Kusmana (2012) "persoalan sampah ternyata bukan hanya milik kaum urban, nan jauh di pinggiran Tasikmalaya, tepatnya sekitar areal pantai selatan Cipatujah, persoalan sampah juga kelihatannya menjadi masalah yang serius".

Selain bercerita tentang pantai dan berbagai permasalahannya, kondisi masyarakat cipatujah pun menjadi sorotan yang tidak kalah menariknya. Masyarakat Cipatujah mayoritas beragama Islam dengan sebagian besar bermata pencaharian sebagai nelayan. Pendidikan masyarakat rata-rata hanya sampai SMP dikarenakan akses menuju lembaga pendidikan cukup sulit saat itu, ditambah kesadaran akan pentingnya pendidikan masih sangat rendah. Masyarakat lebih memilih bekerja mencari uang untuk menghidupi keluarga daripada harus sekolah. Masyarakat dengan lemah ekonomi dan lemah pendidikan akan sangat mudah di provokasi sehingga adanya program peningkatan ekonomi dan pendidikan bagi masyarakat di lingkungan pesisir pantai cipatujah. Berdasarkan permasalahan yang diungkap di atas, maka masalah lingkungan pantai menjadi sorotan utama karena dikabarkan bahwa masyarakat terjangkit wabah penyakit chikungunya dan malaria yang di akibatkan kurang bersihnya lingkungan.

Oleh karena itu, pengelolaan sampah pantai melalui "decou-santai" diharapkan mampu memberikan solusi bagi peningkatan ekonomi masyarakat serta meningkatkan kepedulian masyarakat terhadap lingkungan. Ide Decou-santai ini muncul dari hasil penelitian sebelumnya yang telah tim lakukan dengan judul uji coba rumah paseban yang di dalamnya ada program kriya mengenai kain flannel dan decoupage. Adapun hasil penelitian menunjukkan bahwa program kriya decoupage mampu meningkatkan motivasi belajar warga belajar kesetaraan. Selain itu berdasarkan angket kepuasan warga belajar yang disebar pada warga belajar menunjukkan bahwa warga belajar merasa puas dengan program rumah paseban yang di dalamnya terdapat program kriya decoupage.

Peneliti ingin mencoba menerapkan hasil penelitian rumah paseban pada masyarakat dengan karakteristik yang berbeda dan kondisi demografis yang berbeda pula. Oleh karena itu, program decou-santai ini diharapkan dapat memberikan manfaat yang sama dengan rumah paseban yang diterapkan pada masyarakat perkotaan yang jauh dari pantai. 


\section{B. LANDASAN TEORI}

Sampah menjadi permasalahan yang tidak ada habisnya di negara berkembang seperti Indonesia. Menurut CNN Indonesia (2016) menyatakan bahwa "Dirjen Pengelolan Sampah, Limbah, dan B3 KLHK Tuti Hendrawati Mintarsih menyebut total jumlah sampah Indonesia di 2019 akan mencapai 68 juta ton, dan sampah plastik diperkirakan akan mencapai 9,52 juta ton atau 14 persen dari total sampah yang ada". Hal ini memberikan dampak pada berbagai sektor pembangunan sehingga perlu segera dicarikan solusi penanganannya. Departemen Kehutanan (2009) mendefinisikan "sampah adalah semua material yang dibuang dari kegiatan rumah tangga, perdagangan, industri dan kegiatan pertanian". Sampah adalah buangan yang dihasilkan dari suatu proses produksi baik industri maupun domestik (rumah tangga). Sementara didalam UU No 18 Tahun 2008 tentang Pengelolaan Sampah, disebutkan sampah adalah sisa kegiatan sehari hari manusia atau proses alam yang berbentuk padat atau semi padat berupa zat organik atau anorganik bersifat dapat terurai atau tidak dapat terurai yang dianggap sudah tidak berguna lagi dan dibuang kelingkungan. Sampah juga tidak selamanya menjadi masalah jika dapat dimanfaatkan secara tepat. Beberapa jenis sampah dapat diolah kembali menjadi sesuatu yang bermanfaat. Adapun sampah terdiri dari beberapa jenis berdasarkan sumbernya yaitu :

1. Sampah yang berasal dari pemukiman (domestic wastes)

Sampah ini terdiri dari bahan-bahan padat sebagai hasil kegiatan rumah tangga yang sudah dipakai dan dibuang, seperti sisa -sisa makanan baik yang sudah dimasak atau belum, bekas pembungkus baik kertas, plastik, daun, dan sebagainya, pakaian -pakaian bekas, bahanbahan bacaan, perabot rumah tangga, daun- daunan dari kebun atau taman

2. Sampah yang berasal dari tempat -tempat umum

Sampah ini berasal dari tempat -tempat umum, seperti pasar, tempat -tempat hiburan, terminal bus, stasiun kereta api, dan sebagainya. Sampah ini berupa kertas, plastik, botol, daun, dan sebagainya.

3. Sampah yang berasal dari perkantoran

Sampah ini dari perkantoran baik perkantoran pendidikan, perdagangan, departemen, perusahaan, dan sebagainya. Sampah ini berupa kertas-kertas, plastik, karbon, klip dan sebagainya. Umumnya sampah ini bersifat anorganik, dan mudah terbakar (rubbish).

4. Sampah yang berasal dari jalan raya

Sampah ini berasal dari pembersihan jalan, yang umumnya terdiri dari : kertas-kertas, kardus-kardus, debu, batu-batuan, pasir, sobekan ban, onderdil-onderdil kendaraan yang jatuh, daun-daunan, plastik, dan sebagainya.

5. Sampah berasal dari industri (industrial wastes) 
Sampah ini berasal dari kawasan industri, termasuk sampah yang berasal dari pembangunan industri, dan segala sampah yang berasal dari proses produksi, misalnya : sampah-sampah pengepakan barang, logam, plastik, kayu, potongan tekstil, kaleng, dan sebagainya.

6. Sampah yang berasal dari pertanian/perkebunan

Sampah ini sebagai hasil dari perkebunan atau pertanian misalnya: jerami, sisa sayur-mayur, batang padi, batang jagung, ranting kayu yang patah, dan sebagainya.

7. Sampah yang berasal dari pertambangan

Sampah ini berasal dari daerah pertambangan, dan jenisnya tergantung dari jenis usaha pertambangan itu sendiri, maisalnya: batu-batuan, tanah/cadas, pasir, sisa-sisa pembakaran (arang), dan sebagainya.

8. Sampah yang berasal dari petenakan dan perikanan

Sampah yang berasal dari peternakan dan perikanan ini, berupa : kotoran-kotoran ternak, sisa-sisa makanan bangkai binatang, dan sebagainya (Notoatmojo, 2003).

Selain berdasarkan sumbernya, sampah dikategorikan berdasarkan zat kimia yang dikandungnya adalah sebagai berikut :

1. Sampah anorganik

Sampah anorganik adalah sampah yang umumnya tidak dapat membusuk, misalnya : logam/besi, pecahan gelas, plastik dan sebagainya.

2. Sampah organic

Sampah organik adalah sampah yang pada umumnya dapat membusuk, misalnya : sisa-sisa makanan, daun-daunan, buah-buahan dan sebagainya.

Sampah berdasarkan dapat dan tidaknya terbakar

1. Sampah yang mudah terbakar, misalnya : kertas, karet, kayu, plastik, kain bekas dan sebagainya.

2. Sampah yang tidak dapat terbakar, misalnya: kaleng-kaleng bekas, besi/logam bekas, pecahan gelas, kaca, dan sebagainya (Notoatmodjo,2003).

Sampah berdasarkan karakteristiknya

1. Abu (Ashes)

Merupakan sisa pembakaran dari bahan yang mudah terbakar, baik di rumah, di kantor maupun industri.

2. Sampah Jalanan (Street Sweeping)

Berasal dari pembersihan jalan dan trotoar, terdiri dari kertas-kertas, kotoran dan daundaunan.

3. Bangkai Binatang (Dead Animal)

Yaitu bangkai binatang yang mati karena bencana alam, penyakit atau kecelakaan. 
4. Sampah pemukiman (Household refuse)

Yaitu sampah campuran yang berasal dari daerah perumahan.

5. Bangkai Kendaraan (Abandoned vehicles)

Yang termasuk jenis sampah ini adalah bangkai mobil, truk, kereta api, satelit, kapal laut dan alat transportas lainnya.

6. Sampah industri

Terdiri dari sampah padat yang berasal dari industri pengolahan hasil bumi, tumbuhtumbuhan dan industri lainnya.

7. Sampah hasil penghancuran gedung/bangunan (Demolotion waste)

Yaitu sampah yang berasal dari perombakan gedung/bangunan.

8. Sampah dari daerah pembangunan

Yaitu sampah yang berasal dari sisa pembangunan gedung, perbaikan dan pembaharuan gedung. Sampah dari daerah ini mengandung tanah batubatuan, potongan kayu, alat perekat, kertas dan lain-lain.

9. Sampah Padat Pada Air Buangan (Sewage Solid)

Sampah yang terdiri dari benda yang umumnya zat organik hasil saringan pada pintu masuk suatu pusat pengolahan air buangan.

10. Sampah Khusus

Yaitu sampah yang memerlukan penanganan khusus dalam pengelolaannya, misalnya kaleng cat, film bekas, zat radioaktif dan zat yang toksis. (Mukono, 2006)

Menurut Slamet (2004) sampah baik kualitas maupun kuantitasnya sangat dipengaruhi oleh berbagai kegiatan dan taraf hidup masyarakat. Beberapa faktor yang penting antara lain :

1. Jumlah Penduduk

Dapat dipahami dengan mudah bahwa semakin banyak penduduk semakin banyak pula sampahnya. Pengelolaan sampah pun berpacu dengan laju pertambahan penduduk.

2. Keadaan sosial ekonomi

Semakin tinggi keadaan sosial ekonomi masyarakat, semakin banyak jumlah perkapita sampah yang dibuang. Kualitas sampahnya pun semakin banyak bersifat tidak dapat membusuk. Perubahan kualitas sampahini, tergantung pada bahan yang tersedia, peraturan yang berlaku serta kesadaran masyarakat akan persoalan persampahan. Kenaikan kesejahteraan inipun akan meningkatkan kegiatan konstruksi dan pembaharuan bangunanbangunan, transportasi pun bertambah, dan produk pertanian, industri dan lain-lain akan bertambah dengan konsekuensi bertambahnya volume dan jenis sampah. 
3. Kemajuan Teknologi

Kemajuan teknologi akan menambah jumlah maupun kualitas sampah, karena pemakaian bahan baku yang semakin beragam, cara pengepakan dan produk manufaktur yang semakin beragam pula.

4. Tingkat pendidikan

Menurut Hermawan (2005) Untuk meningkatkan mutu lingkungan, pendidikan mempunyai peranan penting karena melalui pendidikan, manusia makin mengetahui dan sadar akan bahaya limbah rumah tangga terhadap lingkungan, terutama bahaya pencemaran terhadap kesehatan manusia dan dengan pendidikan dapat ditanamkan berpikir kritis, kreatif dan rasional. Semakin tinggi tingkat pendidikan selayaknya semakin tinggi kesadaran dan kemampuan masyarakat dalam pengelolaan sampah.

Pengelolaan sampah menjadi solusi dari permasalahan sampah yang menumpuk di Indonesia. Namun cara pengolahan sampah juga tidak sembarangan agar sampah tidak menjadi masalah baru. Berikut adalah beberapa metode pengolahan sampah yaitu melalui penerapan prinsip 3-R, 4-R atau 5-R. Prinsip-prinsip yang dapat diterapkan dalam penanganan sampah misalnya dengan menerapkan prinsip 3-R, 4-R atau 5-R. Penanganan sampah 3-R adalah konsep penanganan sampah dengan cara Reduce (mengurangi), Reuse (menggunakan kembali), Recycle (mendaur ulang sampah), sedangkan 4 -R ditambah Replace (mengganti) mulai dari sumbernya. Prinsip 5 -R selain 4 prinsip tersebut di atas ditambah lagi dengan Replant (menanam kembali). Penanganan sampah 4 -R sangat penting untuk dilaksanakan dalam rangka pengelolaan sampah padat perkotaan yang efisien dan efektif, sehingga diharapkan dapat mengurangi biaya pengelolaan sampah.

1. Reduce

Prinsip Reduce dilakukan dengan cara sebisa mungkin melakukan minimalisasi barang atau material yang digunakan. Semakin banyak kita menggunakan material, semakin banyak sampah yang dihasilkan. Menurut Suyoto (2008) tindakan yang dapat dilakukan berkaitan dengan program reduce:

a. Hindari pemakaian dan pembelian produk yang menghasilkan sampah dalam jumlah besar

b. Gunakan kembali wadah/kemasan untuk fungsi yang sama atau fungsi lain-Gunakan baterai yang dapat di charge kembali

c. Jual atau berikan sampah yang terpilah kepada pihak yang memerlukan

d. Ubah pola makan (pola makan sehat : mengkonsumsi makanan segar, kurangi makanan kaleng/instan)

e. Membeli barang dalam kemasan besar (versus kemasan sachet)

f. Membeli barang dengan kemasan yang dapat di daur ulang (kertas, daun dan lain-lain)

g. Bawa kantong/tas belanja sendiri ketika berbelanja 
h. Tolak penggunaan kantong plastik

i. Gunakan rantang untuk tempat membeli makanan

j. Pakai serbet/saputangan kain pengganti tisu

k. Kembali kepemakaian popok kain bagi para ibu

2. Reuse

Prinsip reuse dilakukan dengan cara sebisa mungkin memilih barang-barang yang bisa dipakai kembali. Dan juga menghindari pemakaian barang-barang yang hanya sekali pakai. Hal ini dapat memperpanjang waktu pemakaian barang sebelum ia menjadi sampah. Menurut Suyoto (2008) tindakan yang dapat dilakukan berkaitan dengan program reuse :

a. Pilih produk dengan pengemas yang dapat didaur ulang

b. Gunakan produk yang dapat diisi ulang (refill)

c. Kurangi penggunaan bahan sekali pakai

d. Plastik kresek digunakan untuk tempat sampah

e. Kaleng/baskom besar digunakan untuk pot bunga atau tempat sampah

f. Gelas atau botol plastik untuk pot bibit, dan macam-macam kerajinan

g. Bekas kemasan plastik tebal isi ulang digunakan sebagai tas

h. Styrofoam digunakan untuk alas pot atau lem

i. Potongan kain/baju bekas untuk lap, keset, dan lain-lain

j. Majalah atau buku untuk perpustakaan

k. Kertas koran digunakan untuk pembungkus

3. Recycle

Prinsip recycle dilakukan dengan cara sebisa mungkin, barang-barang yang sudah tidak berguna lagi, bisa didaur ulang. Tidak semua barang bisa didaur ulang, namun saat ini sudah banyak industri non-formal dan industri rumah tangga yang memanfaatkan sampah menjadi barang lain. Menurut Suyoto (2008) tindakan yang dapat dilakukan berkaitan dengan program recycle:

a. Mengubah sampah plastik menjadi souvenir

b. Lakukan pengolahan sampah organik menjadi kompos

c. Mengubah sampah kertas menjadi lukisan atau mainan miniature

4. Replace

Prinsip replace dilakukan dengan cara lebih memperhatikan barang yang digunakan sehari-hari. Dan juga mengganti barang-barang yang hanya bisa dipakai sekali dengan barang yang lebih tahan lama. Prinsip ini mengedepankan penggunaan bahan-bahan yang ramah lingkungan seperti mengganti kantong plastik dengan keranjang saat berbelanja, atau hindari penggunaan styrofoam karena banyak mengandung zat kimia berbahaya. 
5. Replant

Prinsip replant dapat dilakukan dengan cara membuat hijau lingkungan sekitar baik lingkungan rumah, perkantoran, pertokoan, lahan kosong dan lain -lain. Penanaman kembali ini sebagian menggunakan barang atau bahan yang diolah dari sampah.

\section{A. Konsep Pemberdayaan Perempuan}

Konsep pemberdayaan lahir dari realitas kehidupan masyarakat yang tidak berdaya atau pihak yang lemah (powerless). Ketidakberdayaan atau memiliki kelemahan dalm aspek pengetahuan, pengalaman, sikap, keterampilan modal usaha, networking, semangat kerja, kerja keras, ketekunan, dan aspek lainnya. Kelemahan diatas mengakibatkan seseorang menjadi ketergantungan, ketdakberdayaan, dan kemiskinan.

Pemberdayaan sangat lekat dengan perempuan dikarenakan pola pikir masyarakat Indonesia masih mengganggap bahwa perempuan berada di bawah laki-laki dalam berbagai hal sehingga dianggap bahwa perempuan adalah makhluk lemah tidak berdaya. Melalui berbagai prgram kesetaraan gender diharapkan para perempuan memiliki peran yang sama dalam pembangunan sebuah bangsa melalui peran-peran yang dijalankan sesuai dengan kodratnya sebagai seorang perempuan.

Pemberdayaan merupakan konsep yang berkaitan dengan kekuasaan. Istilah kekuasaan seringkali identik dengan kemampuan individu untuk membuat dirinya atau pihak lain melakukan apa yang diinginkannya. Dengan kata lain, kekuasaan menjadikan orang lain sebagai objek dari pengaruh atau keinginan dirinya.

Pemberdayaan adalah suatu proses memberikan daya/ kekuasaan pada pihak yang dianggap lebih lemah, dan mnegurangi kekuasaan kepada pihak yang berkuasa sehingga terjadi keseimbangan (Djohani, 2003). Dengan kata lain, pemberdayaan adalah memberi kesempatan pada seseorang untuk mampu menguasai dirinya sendiri atas kehidupannya sendiri.

Bukan hanya itu, ada makna yang terkandung dalam konsep pemberdayaan itu sendiri yaitu tidak sekedar memberikan kewenangan ada pihak yang lemah namun ada makna proses pendidikan dalam meningkatkan kualitas individu, kelompok atau masyarakat sehingga mampu berdaya, memiliki daya saing, serta mampu hidup mandiri. Dalam hal ini pemberdayaan perempuan adalah membantu para perempuan untuk dapat hidup mandiri terutama saat suami mereka sudah tidak ada. Karena melalui pemberdayaan perempuan, perempuan dibentuk menjadi seseorang yang siap mandiri dan tidak bergantung pada pria.

Fokus pemberdayaan tidak hanya pada individu, namun dapat juga komunitas. Pemberdayaan yang bersifat individu merupakan proses untuk meningkatka pengetahuan, motivasi keterampilan, pengalaman individu, sehingga memiliki daya saing untuk mencapai 
kemandirian. Sedangkan pemberdayaan yang besifat komunitas bertujuan untuk membentuk komunitas yang mandiri dan mampu mengatur komunitasnya sendiri.

Pemberdayaan juga menekankan pada proses, bukan semata-mata hasil (output) dari proses tersebut. Oleh karena itu ukuran keberhasilan pemberdayaan adalah seberapa besar partisipasi atau keberdayaan yang dilakukan oleh individu atau masyarakat. Semakin banyak masyarakat yang terlibat dalam proses tersebut, berarti semakin semakin berhasil kegiatan tersebut. Menurut Haryono Suyono (Anwas, 2014:51) 'Pemberdayaan bukan membentuk superman melainkan membentuk supertim' bagaimana filsafat orang jepang mengatakang bahwa "5 kepala akan lebih baik dari 1 kepala" artinya bahwa ada kekuatan dari sebuah tim dibandingan hanya individu.

\section{B. Decoupage}

Decoupage, yang berasal dari bahasa Prancis découper atau berarti memotong, merupakan kerajinan atau bentuk seni yang memerlukan potongan-potongan bahan (biasanya kertas) yang ditempel pada objek dan kemudian dilapisi dengan pernis atau pelitur. Proses ini membuat tampilan potongan-potongan kertas yang rata tampak dalam dan membuat pola serta gambar terlihat seolah-olah dilukis pada objek yang diproses dengan teknik decoupage. Decoupage adalah cara menyenangkan dan mudah untuk mendekorasi objek apa saja, termasuk benda-benda di rumah mulai dari vas kecil hingga furnitur berukuran besar. Kemungkinannya sangatlah banyak. Namun, untungnya, decoupage bisa dipelajari relatif cepat hanya dengan beberapa langkah.

Peralatan yang dibutuhkan dalam decoupage antara lain adalah :

1. Lem

2. Kuas cat

3. Pelitur, pernis, atau pelapis khusus decoupage

4. Gunting

5. Objek yang akan dilapisi dengan decoupage

6. Bahan-bahan decoupage (guntingan koran dan majalah, potongan kertas, dan lain sebagainya)

Adapun langkah pembuatan decoupage adalah sebagai berikut :

\section{Pilih Bahan}

Pilihlah objek yang ingin dihias dan kumpulkan bahan-bahan untuk mendekorasi objek tersebut. Anda dapat menggunakan bahan-bahan apa saja untuk decoupage, misalnya kartu, kertas tisu, kertas pembungkus kado, tas belanja dari kertas, guntingan majalah, rice paper (semacam kulit lumpia terbuat dari tepung beras), potongan kain tipis, atau (tentu saja) kertas khusus untuk decoupage. Anda juga bisa menggunakan kertas buatan sendiri. Secara umum, 
semakin lembut dan fleksibel bahannya, maka akan semakin mudah digunakan jika Anda melakukan decoupage pada permukaan yang berlekuk-lekuk.

a. Jangan gunakan kertas bergambar yang dicetak menggunakan printer (pencetak) ink-jet karena warnanya akan membaur dengan lapisan atas. Sebagai alternatifnya, fotokopi kertas tersebut dengan fotokopi berwarna yang menggunakan tinta yang tidak akan membaur.

b. Cobalah menggunakan kain atau wallpaper untuk menutupi permukaan yang luas secara langsung. Anda bisa menggunakan bahan ini sebagai latar belakang sebelum menambahkan bahan-bahan decoupage yang lain.

c. Jangan gunakan bahan-bahan yang terlalu tebal, karena bisa menonjol keluar dari permukaan objek dan bisa lepas secara tidak sengaja. Anda tentu ingin menjaga agar permukaan objek dapat tampak serapi mungkin.

d. Gunakan benda-benda yang ada di sekitar Anda untuk di-decoupage agar menghemat uang untuk pembelian bahan-bahan. Lembaran kertas dari surat-surat lama, brosur, koran, serta buku-buku dan majalah lama sangat baik untuk digunakan.

2. Guntinglah lembaran-lembaran kertas.

Anda dapat menggunakan seluruh lembaran kertas, sobekan, atau guntingan agar tercipta bentuk dan desain yang menarik. Gunakan gunting atau pisau khusus kerajinan tangan untuk membuat bentuk yang diinginkan, dengan memegang gunting sedemikian rupa sehingga posisinya agak miring ke arah kanan. Cara ini akan menghasilkan pinggiran yang lebih halus dan menyerong.

a. Menyobek kertas akan menghasilkan pinggiran yang lebih halus. Untuk menyobek kertas agar pinggirannya halus, lipatlah kertas sepanjang garis yang akan disobek dan ratakan menggunakan kuku. Lakukan lagi pada arah yang berlawanan lalu sobek kertas tersebut.

b. Tak perlu menutupi seluruh permukaan dengan potongan kertas. Siapkan saja sebanyak mungkin yang Anda perlukan untuk proyek ini.

3. Rencanakan proyek decoupage Anda.

Buatlah sketsa rancangan atau letakkan guntingan kertas pada objek tanpa direkatkan lalu fotolah agar Anda ingat penataannya.

a. Jika tidak suka merencanakan sesuatu, jangan ragu untuk merekatkan langsung potonganpotongan kertas tanpa rencana sebelumnya. Perhatikan baik-baik komposisinya untuk memastikan Anda merekatkan potongan-potongan kertas tersebut secara konsisten.

b. Pertimbangkan warna dan tekstur potongan kertas yang direkatkan. Padu-padankan warnawarna yang berbeda atau cobalah menggunakan berbagai warna pada proyek Anda.

4. Siapkan permukaan objek.

Pastikan objek yang Anda dekorasi dalam keadaan bersih dan kering, selain itu, tambal

juga lekukan-lekukan yang dalam, dan ampelas permukaan objek untuk menghilangkan 
tonjolan dan kekurangan jika perlu. Jika Anda ingin mengecat atau memberi pelitur, Anda harus melakukannya hal ini sebelum menempelkan potongan kertas di atasnya.

a. Untuk beberapa objek seperti kayu dan logam, Anda perlu memberikan cat dasar pada permukaannya dengan lapisan cat lateks agar potongan kertas menempel dengan baik.

b. Jika Anda ingin membersihkan benda dengan air, pastikan benda tersebut sudah kering sebelum direkatkan agar semua bahan dapat menempel dengan baik.

5. Lindungi area kerja Anda dengan cara menutupnya dengan kertas koran.

6. Gunakan lem yang sesuai dengan permukaan objek dan potongan-potongan kertas.

Anda dapat menggunakan lem putih, namun akan lebih mudah jika dicampur dengan air. Perbandingannya adalah 50 persen lem dan 50 persen air. Pastikan saat mencampur lem ini, wadah berada dalam keadaan tertutup. Lalu, guncang-guncangkan wadah tersebut.

7. Bubuhkan lem.

Gunakan kuas cat untuk membubuhkan lapisan tipis lem pada permukaan objek dan bagian belakang potongan kertas. Pastikan Anda membubuhkan lem secara merata dan sampai pinggiran potongan kertas.

8. Tempelkan satu per satu potongan kertas pada permukaan objek. Letakkan potongan kertas pada area yang akan dibubuhi lem. Letakkan kertas dengan hati-hati agar tidak timbul lekukan dan kekusutan. Ratakan agar rapi menggunakan brayer (rol kecil) atau stik es krim, ratakan dari tengah permukaan ke arah luar. Ulangi langkah ini dengan potongan-potongan kertas lain.

9. Untuk menghasilkan tampilan yang lebih rumit, letakkan beberapa lapisan potongan kertas. Letakkan lapisan pertama lalu tempelkan lapisan-lapisan berikutnya pada lapisan pertama, sebagian menutupi lapisan di bawahnya.

10. Biarkan lem mengering. Pastikan seluruh potongan kertas benar-benar mengering seluruhnya sebelum dilanjutkan. Jika Anda meletakkan beberapa lapisan, pastikan tiap lapisan kering sebelum mulai dilapisi dengan potongan kertas berikutnya.

11. Jika ada pinggiran yang menggulung, Anda bisa meratakannya dengan silet agar lebih rap

12. Aplikasikan pernis atau pelitur.

Lapisi decoupage dengan beberapa lapisan pelapis yang sesuai, seperti pelapis yang khusus diformulasikan untuk decoupage (tersedia di toko kerajinan seni dan hobi), pernis, atau pelitur. Biarkan tiap lapisan mengering sebelum diaplikasikan lapisan selanjutnya.

13. Ampelas decoupage yang sudah diberi pelapis.

Setelah pelapis kering, ampelas dengan kertas ampelas 400 grit untuk menghilangkan noda. Gunakan kain yang lembap untuk menghilangkan sisa-sisa dari pengampelasan. Jika belum dilapisi dengan pelapis untuk menutupi permukaan dan potongan kertas, jangan mengampelas objek. 
14. Lanjutkan untuk mengaplikasikan pernis atau pelitur.

Tampilan decoupage yang unik tercipta dari beberapa lapisan pelapis. Jumlah lapisannya terserah Anda. Anda mungkin perlu 4 atau 5 lapisan, tergantung pada pelapis yang Anda gunakan. Beberapa seniman decoupage menggunakan 30 atau 40 lapisan. Ingat, biarkan tiap lapisan mengering sebelum mengaplikasikan lapisan selanjutnya, dan ampelas decoupage setelah objek diberi beberapa lapisan pelapis untuk hasil terbaik.

\section{HASIL DAN PEMBAHASAN}

\section{Profil Desa Sindangkerta}

Desa Sindangkerta merupakan salah satu desa dari 15 desa yang berada di Kecamatan Cipatujah Kabupaten Tasikmalaya Provinsi Jawa Barat. Desa Sindangkerta juga dilewati oleh jalur Provinsi yang merupakan jalur Pantai Selatan Pangandaran - Cipatujah - Pamuengpeuk Pelabuhan Ratu - Sin Jangbarang Cianjur. Desa Sindangkerta mempunyai panorama alam pesisir pantai yang cukup indah dimana banyak pendatang berekreasi atau berenang di pantai Taman Lengsar dan Taman Saut. Di samping itu, di sekitar pantai banyak terdapat terumbu karang serta biota laut dari berbagai macam dan jenis yang sering dijadikan bahan penelitian oleh para pelajar dan mahasiswa dari SLTA/Perguruan Tinggi Negeri maupun Swasta. Selain itu, terdapat penangkaran penyu yang terletak di Dusun Karanganyar dan daerah konservasi penyu sepanjang $3 \mathrm{~km}$ yang juga sering dijadikan bahan penelitian. Di samping panoramapantai yang cukup indah juga memiliki alam perbukitan serta hutan yang cukup hijau dan hamparan sawah yang cukup luas di mana Desa Sindangkerta mempunyai luas wilayah sekitar $2351 \mathrm{Ha}$.

Keadaan hutan pesisir di daerah bentang lahan yang berupa dataran pesisir pantai yang terbentang kurang lebih 42 hektare sangat memprihatinkan. Hal ini disebabkan oleh abrasi pantai tiap tahun yang menggerus areal pesisir pantai tersebut. Belum lagi ulah tangan manusia yang tidak bertanggungjawab untuk mengantisipasi hal tersebut. Maka, sekelompok masyarakat sepakat untuk membuat suatu wadah yang peduli akan penyelamatan wilayah pasir pantai, minimal di Desa Sindangkerta. Wadah ini juga dibuat sekaligus untuk meningkatkan gotong royong dan sifat rasa memiliki dan tanggung jawab akan lingkungan pesisir pantai. Saat ini, masyarakat Desa Sindangkerta yang tinggal di wilayah pesisir pantai sudah menyadari pentingnya hutan penyangga abrasi pantai. Salah satu penyebabnya adalah tsunami yang pernah terjadi di Desa Sindangkerta ini.

Desa Sindangkerta memiliki luas 2.6 Ha dengan jumlah penduduk sebanyak 6.405 Jiwa yang terbagi dalam 12 RW dan 46 RT. Penduduk asli sindangkerta kebanyakan sudah meninggalkan desa sindangkerta dan memilih tinggal di kota tasik, mungkin dikarenakan akses yang cukup jauh untuk ke kota dan fasilitas umum lainnya. Namun tidak sedikit kini desa Sindangkerta dipenuhi oleh penduduk pendatang yang berasal dari jawa tengah dan sekitarnya. 
Sehingga untuk menemukan penduduk asli sindangkerta kini sedikit sulit. Tapi hal ini tidak membuat program berhenti, pengabdian pada masyarakat pribumi maupun pendatang tidak menjadi halangan. Hal yang paling penting adalah program yang diselenggarakan dapat bermanfaat bagi masyarakat.

Penyelenggaraan pengabdian pada masyarakat Cipatujah ini dilaksanakan melalui beberapa tahap mulai dari perencanaan sampai evaluasi sebagai berikut :

1. Perencanaan

Pada tahap ini, dilakukan beberapa kegiatan yaitu:

a. Menyiapkan instrumen identifikasi;

Instrumen identifikasi disusun sebagai alat untuk mempermudah dalam proses identifikasi. Instrumen berisi tentang identitas sasaran peserta program. Adapun instrumen terlampir.

b. Menyiapkan sarana dan bahan praktikum;

Tabel 1.

Sarana dan Bahan Praktikum

\begin{tabular}{|l|c|}
\hline \multicolumn{1}{|c|}{ Alat dan Bahan } & Jumlah \\
\hline Kuas & 1 \\
\hline Pallet & 1 \\
\hline Cat decoupage & 1 \\
\hline Lem decoupage & 1 \\
\hline Paper napkin & 1 \\
\hline Vernish & 1 \\
\hline Talenan kayu sebagai media decoupage & 1 \\
\hline
\end{tabular}

c. Identifikasi sasaran peserta program;

Berdasarkan hasil identifikasi diperoleh data diantaranya adalah :

1) Masyarakat cipatujah memiliki potensi lokal namun belum bisa memanfaatkan dengan maksimal

2) Kebanyakan masyarakat adalah pendatang

3) Potensi wisata berdampak pada penumpukan sampah

4) Masyarakat sangat berminat untuk memiliki keterampiln yang dapat menghasilkan pendapatan tambahan

2. Pelaksanaan

Adapun program dilaksanakan di gedung serbaguna Mess Pemda yang berlokasi cukup dekat dengan posko mahasiswa dan dosen kelompok desa sindangkerta cipatujah pada hari Selasa, 7 Februari 2017 Pukul 08.00-12.00 Wib. Program berjalan dengan lancar, dihadiri oleh perwakilan desa sekaligus membuka program seminar pengabdian pada masyarakat. Acara 
dihadiri oleh 40 ibu rumah tangga usia produktif sebagaimana hasil identifikasi sasaran pada perencanaan program.

Acara diakhiri dengan memberikan doorprice pada peserta yang mampu menjawab pertanyaan yang diajukan oleh nara sumber. Doorprice yang diberikan adalah hasil decoupage. Setelah itu, perwakilan peserta diminta untuk memberikan kesan dan pesan mengenai program yang sudah terlaksana.

3. Evaluasi

Sebagian besar peserta bahwa materi yang telah disampaikan sangat menarik dan merupakan hal baru bagi mereka. Sehingga sangat menginspirasi mereka untuk membuka usaha baru dalam meningkatkan penghasilan

\section{KESIMPULAN}

Program pengabdian dengan tema memanfaatkan sampah pantai berupa botol plastik ataupun botol kaca ini berjalan lancar meskipun pada pelaksanaannya tidak semua peserta dapat praktikum dikarenakan keterbatasan waktu dan biaya sehingga hanya diambil sampel. Namun walaupun demikian, materi decoupage ini dapat tersampaikan dan diterima oleh peserta pengabdian.

Decoupage merupakan kegiatan yang menyenangkan dan mudah. Namun untuk menghasilkan produk yang berkualitas memang dibutuhkan bahan yang baik dan ini tentunya terbentur dengan lokasi yang cukup sulit diakses sehingga decoupage masih terbatas dengan bahan yang ada di lingkungan sekitar.

\section{E. DAFTAR PUSTAKA}

Agustine, A I. (2012). Analisis Faktor Potensi Pesisir Cipatujah sebagai Destinasi Wisata di Kabupaten Tasikmalaya. Skripsi pada UPI Bandung. Diterbitkan. repository.upi.edu.

CNN Indonesia. 2016. Indonesia penyumbang sampah plastik terbesar ke-dua dunia. Tersedia [online]:http://www.cnnindonesia.com/gaya-hidup/20160222182308-277112685/indonesia-penyumbang-sampah-plastik-terbesar-ke-dua-dunia/. Diakses 5 januari 2017.

Dephut] Departemen Kehutanan. (2009). Pedoman Inventarisasi Hutan Menyeluruh Berkala (IHMB) pada Usaha Pemanfaatan Hasil Hutan Kayu Pada Hutan Produksi. Peraturan Menteri Kehutanan No.P.33/Menhut-II/2009

Djohani. (2003). Partisipasi, Pemberdayaan, dan Demokratisasi Komunitas: Reposisi Participatory Rural Appraisal (PRA) dalam Program Pengembangan Masyarakat, Bandung: Studio Driya Media

Hermawan. (2005). Penelitian Bisnis Paradigma Kuantitatif. Jakarta:Gramedia Media Sarana Indonesia. 
Kusmana, U. (2012). Sampah dan Pesona Wisata Pantai. Tersedia [online]: http://www.kompasiana.com/kusmanausman/sampah-dan-pesona-pariwisatapantai_55104b0e813311ab36bc62fc

Mukono. (2006). Prinsip Dasar Kesehatan lingkungan Surabaya: Airlangga University Press.

Mulyadin. (2014). Pengembangan Atraksi Wisata Pantai Cipatujah sebagai Kawasan Wisata Bahari di Kabupaten Tasikmalaya. Skripsi pada UPI Bandung. Diterbitkan. repository.upi.edu./ perpustakaan.upi.edu

Notoatmodjo. (2003). Pendidikan Dan Perilaku Kesehatan. Rineka Cipta. Jakarta.

Perundang-undangan. (2008). Undang-undang Republik Indonesia Nomor 18 Tahun 2008 tentang Pengelolaan Sampah. Jakarta: Sekretariat Negara.

Slamet. (2004). Kesehatan Lingkungan. Yogyakarta. Gajah Mada University Press.

Suyoto. (2008). Fanomena Gerakan Mengolah Sampah. Jakarta : Prima Media. 